\title{
Antioxidants and the Integrity of Ocular Tissues
}

\author{
Marcela P. Cabrera ${ }^{1}$ and Ricardo H. Chihuailaf ${ }^{2}$ \\ ${ }^{1}$ Escuela de Graduados, Facultad de Ciencias Veterinarias, Universidad Austral de Chile, P.O. Box 567, 5110566 Valdivia, Chile \\ ${ }^{2}$ Instituto de Ciencias Clínicas Veterinarias, Facultad de Ciencias Veterinarias, Universidad Austral de Chile, P.O. Box 567, \\ 5110566 Valdivia, Chile
}

Correspondence should be addressed to Ricardo H. Chihuailaf, rchihuailaf@uach.cl

Received 1 January 2011; Revised 21 March 2011; Accepted 13 May 2011

Academic Editor: Fernando Wittwer Menge

Copyright (๑) 2011 M. P. Cabrera and R. H. Chihuailaf. This is an open access article distributed under the Creative Commons Attribution License, which permits unrestricted use, distribution, and reproduction in any medium, provided the original work is properly cited.

\begin{abstract}
Oxygen-derived free radicals are normally generated in many pathways. These radicals can interact with various cellular components and induce cell injury. When free radicals exceed the antioxidant capacity, cell injury causes diverse pathologic changes in the organs. The imbalance between the generation of free radicals and antioxidant defence is known as oxidative stress. The eye can suffer the effect of oxidative damage due to the etiopathogenesis of some pathological changes related to oxidative stress. This paper reviews the role of oxidative stress in the onset and progression of damage in different eye structures, the involvement of the antioxidant network in protecting and maintaining the homeostasis of this organ, and the potential assessment methodologies used in research and in some cases in clinical practice.
\end{abstract}

\section{Introduction}

The eye is an organ that captures light stimuli of the environment and transforms these light signals into nerve impulses that travel through the optic nerve to be processed in images by the brain. Today, there has been an increase in visits for eye diseases in both human medicine and veterinary medicine. The main causes of this increase can be attributed to xenobiotics derived of environmental pollution [1], increasing of the ultraviolet radiation intensity [2], and feeding based on fats and carbohydrates associated with physical inactivity and increasing of degenerative diseases such as diabetes and cardiovascular problems $[3,4]$.

All the above factors can generate harmful chemicals to ocular tissues and are called oxidants agents or free radicals (FRs). To protect against external agents, the eye has several nonspecific defence mechanisms, such as eyelids, tear film, cornea, and lens. When harmful agents have overcome these barriers, other specific mechanisms operate based on molecules called antioxidants [5].

This paper reviews the role of oxidative stress in the onset and progression of damage in different eye structures, the involvement of the antioxidant network in protecting and maintaining the homeostasis of this organ, and the assessment methodologies used in research and in some cases in clinical practice.

1.1. Free Radicals. An FRs represents any chemical species that has one or more unpaired electrons rotating in its external atomic orbits [6]. Several authors have classified FRs according to the functional group in their molecule. The most frequent one is an oxygen FRs, in which oxygen is the functional centre. This species is called reactive oxygen species (ROS) and is the most relevant in eye damage. ROS is a generic name that includes FRs and those chemical species that act like oxidants but that are not FRs. The first group includes superoxide anion $\left(\mathrm{O}_{2}{ }^{\bullet-}\right)$, hydroxyl radical $\left(\mathrm{OH}^{\bullet-}\right)$, peroxyl radical $\left(\mathrm{LOO}^{\bullet}\right)$, and alkoxyl $\left(\mathrm{LO}^{\bullet}\right)[3,7]$.

Nonradical species behave as oxidants or are easily converted into FRs. Within this group are hydrogen peroxide $\left(\mathrm{H}_{2} \mathrm{O}_{2}\right)$, hypochlorous acid $(\mathrm{HClO})$, singlet oxygen $\left({ }^{1} \mathrm{O}_{2}\right)$, and ozone $\left(\mathrm{O}_{3}\right)[8]$.

ROS are generally formed from normal metabolic reactions and exogenous factors can increase them $[3,9]$. The first ones are mainly those formed in the mitochondria during ATP synthesis, in the peroxisomes during $\beta$ oxidation of fatty acids and D-amino acids, as consequence of activation of P-450 enzyme system or by macrophages 
and neutrophils as part of the immune response [10-12]. The exogenous factors can include an excessive intake of some transition metals such as iron $(\mathrm{Fe})$ and copper $(\mathrm{Cu})$, ultraviolet radiation, drugs, and pollution $[12,13]$.

1.2. Oxidative Stress. This alteration is produced when there is an imbalance in FRs generation and the antioxidant defence mechanism. Normal metabolic processes generate large amounts of ROS. However, when FRs generation exceeds the capacity of adaptation and cellular defence, a condition known as oxidative stress is produced. This does not define if the alteration is due to an increase in FRs or to a decrease in a homeostatic response in tissues. Given that oxidative injury can be related to a deficiency of protective substances and several protective substances are nutrients, a close relationship between oxidative stress and nutritional state can be established. Oxidative stress affects the cell integrity, because biomolecules such as DNA, proteins, and lipids are damaged consequence of this process. Almost every biological macromolecules can be oxidized by ROS; however, lipids and proteins are the most labile biomolecules presents in the eyeball $[3,9]$.

1.2.1. Lipid Peroxidation. The action of ROS on lipids is known as lipoperoxidation or lipid peroxidation (LPO), and the mechanism, measurement, and interpretation have been widely reviewed. The LPO is particularly destructive, for it develops as a self-perpetrating chain reaction. This process is initiated when ROS removes a hydrogen atom from the methylene group of a polyunsaturated fatty acid (PUFA) and form a lipid FRs. Quickly, it adds oxygen molecule and becomes a fatty acid peroxyl FRs and oxidized to other PUFA initiating new reactions. This mechanism is facilitated by the presence of transition metal ions $(\mathrm{Cu}$ and $\mathrm{Fe})$ and the double bonds contained in the chain of PUFA $[7,8]$. The end products of LPO are degraded and originate new cytotoxic compounds such as 4-hydroxynonenal (4-HNE) and malondialdehyde (MDA). The consequences of oxidative damage to PUFA are more evident when they are part of cellular or subcellular membranes, because it alters its cohesion, fluidity, permeability, and metabolic function [6, $9,14]$.

1.2.2. Protein Oxidation. While proteins, peptides, and amino acids are also targets for ROS, its modification is less harmful than lipids, because the progress of reaction is slow. However, the ocular tissue has a high percentage of proteins, and then, any alteration on the proteins is very important $[15,16]$. It has been observed that the presence of significant amounts of aromatic and sulfur amino acids in a protein structure makes it more vulnerable to the FRs [6]. This condition is observed in the lens, whose protein composition contains high proportions of tryptophan, tyrosine, phenylalanine, histidine, methionine, and cysteine amino acids that can be modified by ROS, producing adducts and aggregation and altered enzyme function. Peptide bonds are also susceptible to be attacked by FRs. These bonds can be modified after the oxidation of proline residues. In addition, end products could amplify the initial damage [13].

\section{Antioxidant Protection Mechanisms Associated to the Eye}

The ocular tissue has a protection system against oxidative damage that can be classified into enzymatic and nonenzymatic antioxidants [17].

2.1. Enzymatic Antioxidants. Enzymatic antioxidants catalyze electron transference from a substrate toward ROS. Later, the substrates or reducing agents used in these reactions are regenerated to be used again, and they achieve this by using the NADPH produced in different metabolic pathways [6]. The main antioxidant enzymes protecting the eye against ROS are superoxide dismutase (SOD), catalase (CAT), and glutathione peroxidase (GPx). Each of these enzymes catalyzes the reduction of a particular type of ROS [18].

2.1.1. Superoxide Dismutase (EC 1.15.1.1, SOD). Superoxide dismutase catalyzes the dismutation of $\mathrm{O}_{2}{ }^{\bullet-}$ into $\mathrm{H}_{2} \mathrm{O}_{2}$ and $\mathrm{O}_{2}$. This enzyme is a metalloprotein and has three isoforms, which have different cellular locations and employ different cofactors. The isoforms Cu-SOD and Zn-SOD are located in the cytosol and extracellular fluid, whereas the isoform Mn-SOD is located in the mitochondrial matrix $[9,19]$. All isoforms have been identified in the cornea (epithelium and endothelium) [18, 20-22], lens epithelium [23], aqueous humor [24], iris, ciliary body [25], and retina (inner segment layer of photoreceptor cells and pigment epithelium) [26, 27].

2.1.2. Glutathione Peroxidase (EC 1.11.1.9, GPx). This selenoprotein can reduce $\mathrm{H}_{2} \mathrm{O}_{2}$ and organic hydroperoxides into water and alcohol, respectively, using reduced glutathione (GSH) as electron donor. Four GPx isoforms have been described, and they are all found in different locations: cellular GPx, extracellular or plasmatic GPx, phospholipid hydroperoxide GPx, and gastrointestinal GPx. All GPx are an important defence against ROS-mediated damage to lipid membranes and other molecules susceptible to oxidation [6]. GPx has been detected in cornea (epithelium and endothelium) $[18,28]$, lens epithelium, aqueous humor [24], ciliary body, choroid, and retina (inner segment layer of photoreceptors and retinal pigment epithelium) $[21,27,29]$.

2.1.3. Catalase (EC 1.11.1.6, CAT). This hemoprotein contains four heme groups. The enzyme is present in peroxisomes mitochondria and cytoplasm and catalyzes the conversion of $\mathrm{H}_{2} \mathrm{O}_{2}$ into $\mathrm{H}_{2} \mathrm{O}$ and $\mathrm{O}_{2}$. This function is shared with GPx, but CAT has higher affinity when $\mathrm{H}_{2} \mathrm{O}_{2}$ is found in high concentrations [14]. CAT has been detected in the cornea (epithelium and endothelium) $[18,28]$, lens epithelium, aqueous humor [24], ciliary body, iris [25], and retina $[26,27]$ of rabbits and rats $[30]$. 
2.2. Nonenzymatic Antioxidants. These antioxidants constitute a heterogeneous group, and they act by donating an electron to an FRs in order to stabilize it and create chemical species that are less noxious to cell integrity [6]. The main nonenzymatic antioxidants present in the globe are ascorbic acid, vitamin E, vitamin A, and GSH [5].

2.2.1. Ascorbic Acid. It is an antioxidant that is soluble at physiological $\mathrm{pH}$ in most tissues as ascorbate anion. Its antioxidant role is to reduce $\mathrm{O}_{2}{ }^{\bullet-}, \mathrm{OH}^{\bullet-}$ and lipid hydroperoxide into more stable forms [14]. Another function of ascorbate is related with the recycling of $\alpha$-tocopheryl radical to $\alpha$-tocopherol. However, this process transforms ascorbate anion into dehydroascorbate anion radical, which can be reduced by dehydroascorbate reductase and GSH returning it to native state. Also, ascorbate can act as a pro-oxidant in the presence of excessive concentrations of ions $\mathrm{Fe}^{+3}$ and $\mathrm{Cu}^{+2}$ $[6,7,14]$. Ascorbate was detected in cornea [31], aqueous humor [32, 33], lens [34], vitreous humor [35], and retina [29].

2.2.2. Vitamin $E$. The term vitamin $\mathrm{E}$ is a generic name for a family of eight compounds, four tocopherols, and four tocotrienols, of which the $\alpha$-tocopherol is the most active antioxidant and the primary defence liposoluble antioxidant in membranes. The $\alpha$-tocopherol converts $\mathrm{O}_{2}{ }^{\bullet-}, \mathrm{OH}^{\bullet-}$ and $\mathrm{LOO}^{\bullet}$ into less reactive molecules. The phenolic hydroxyl on the chroman ring is responsible for the antioxidant function [9]. In parallel, $\alpha$-tocopherol can stop the chain reaction of ROS during the attack on cell membranes [36]. To stabilize ROS, the $\alpha$-tocopherol is converted into the $\alpha$-tocopheryl radical, whose shape is stable and does not react with biomolecules. $\alpha$-tocopheryl radical can be regenerated to its original through reactions mediated by vitamin $\mathrm{C}, \mathrm{GSH}$, and lipoic acid [6]. The antioxidant ability of $\alpha$-tocopherol depends on the concentrations of those compounds, which keep $\alpha$-tocopherol in its reduced state in instances of oxidative stress [36]. It is possible that an overproduction of ROS can cause a significant drop of active vitamin $\mathrm{E}$ tissue concentration. The $\alpha$-tocopherol has been detected in lens [37], aqueous humor, and retina [29].

2.2.3. Vitamin $A$. This generic term includes those compounds from animals that show vitamin A biological activity. The major precursor of vitamin $\mathrm{A}$ is $\beta$-carotene, which is the most efficient neutralizer of ${ }^{1} \mathrm{O}_{2}$. The antioxidant properties of vitamin A derive from its chemical structure, which consists of long chains of conjugated double bonds, this allows to convert $\mathrm{O}_{2}{ }^{--}$y $\mathrm{LOO}^{\bullet}$ into less reactive substances [14]. Carotenoids are effective antioxidants but differ in their concentrations in ocular tissues. Other carotenoids, with the exception of lutein/zeaxanthin, are found only in trace quantities in the ocular tissues except in the ciliary body, where aqueous humor is produced. In contrast, lutein and zeaxanthin are found in high concentrations in some ocular tissues, such as the macula, retina, and lens $[37,38]$.

2.2.4. Glutathione (GSH). Its reduced form corresponds to a tripeptide (gamma glutamyl-cysteinyl-glycine) with a sulfhydryl group $(-\mathrm{SH})$ in the active site. GSH transfers electrons to oxidized specie such as hydroxyl radicals and carbonyls, becoming in turn an oxidized product (GSSG) $[9,14]$. During this reaction, GSH donates a pair of $\mathrm{H}$ so that two GSH molecules are oxidized to produce GSSG. Also, GSH acts as cosubstrate of GPx in the removal of $\mathrm{H}_{2} \mathrm{O}_{2}$ and organic peroxides, and it can reduce tocopheryl FRs and dehydroascorbate returning them to original form $[6,36]$.

GSH is important for the maintenance of lenticular proteins in a reduced state [30]. This has been found in lens $[39,40]$, cornea, and retina [41], being next to ascorbic acid one of the main mechanism of defence against photooxidation [15].

\section{Oxidative Stress and Globe}

The eye is affected by oxidative stress due to its physical and metabolic characteristics. The eye is a metabolically active organ, consuming large amount of ATP. In addition, the transparency of the cornea, aqueous humor, lens, vitreous and retina allows a constant photochemical ROS generation $[17,32]$. All ocular tissues and fluids are susceptible to damage by oxidative stress; however, those described below affect severely the function of the eye due to the physical changes they undergo [18].

3.1. Cornea. The main ROS generation occurs in the cornea due to high exposure to ultraviolet radiation [18]. The cornea is the main barrier which stops ultraviolet radiation (UVAUVB). It absorbs $92 \%$ of UV-B and $60 \%$ of UV-A, and the highest degree of absorption occurs in the surface layers [42, 43].

UV radiation produces changes in the cornea, such as blocking epithelial cells proliferation and reduced epithelial thickness [44], decrease in corneal antioxidant such CAT, GPx, and SOD [18], decreased $\mathrm{Na}^{+} / \mathrm{K}^{+}$ATPase in the corneal epithelium and endothelium, causing significant increase in corneal hydration and changes in the transparency of the cornea and release of proinflammatory cytokines $[2,20,45$, 46]. UV radiation also causes alteration of the physiological properties of glycosaminoglycans in the stroma, becoming more susceptible to degradation by tissue enzymes from stimulated phagocytic cells [18, 47].

It has been determined that the primary antioxidant defence is ascorbic acid (highly concentrated in the corneal centre, right in the pupil area) and SOD activity. CAT and GPx enzymes have a secondary role [33]. However, when an episode of oxidative stress is triggered, the enzymatic activity begins to reduce, first CAT activity, then GPx activity, and finally SOD activity begin to reduce, thereby increasing the amount of $\mathrm{H}_{2} \mathrm{O}_{2}$ further damaging the cornea $[18,20]$.

3.2. Aqueous Humor. ROS generation in the aqueous humor is due primarily to UV radiation [18] and inflammatory processes that occur in adjacent structures [48]. Aqueous humor contains ascorbic acid, proteins, and some amino acids (tyrosine, phenylalanine, cysteine, and tryptophan), involved in UV-B absorption by allowing only a small fraction of these radiation reach the posterior segment of globe [18]. The UV radiation absorption in the aqueous 
humor causes an increase in $\mathrm{H}_{2} \mathrm{O}_{2}$ concentration, which, in turn, decreases the metabolism of GSH. It has been determined that ascorbic acid plays a fundamental role as UV filters in mammals, having a greater concentration in the aqueous humor from diurnal animals than nocturnal animals [17]. Also, ascorbic acid concentration in aqueous humor is higher than blood plasma [32, 48, 49].

Another source of formation of large amounts of ROS was observed after surgery, paracentesis, or uveitis due to an increase in the amount of proteins and cells in aqueous humor $[32,48]$. There is evidence that after lenticular surgery, the total antioxidant capacity of aqueous humor decreased up to $40 \%$, mainly due to the decreased concentration of ascorbic acid [32, 48]. This fact was also observed in human patients with idiopathic acute anterior uveitis [50].

The increase in the $\mathrm{H}_{2} \mathrm{O}_{2}$ concentration in the aqueous humor may cause damage to corneal endothelium, lens, and ciliary body, especially trabecular network. In vitro studies have shown that a decrease in the facility of aqueous humor outflow occurs when an increased of $\mathrm{H}_{2} \mathrm{O}_{2}$ concentration is present, and this may be grounds for diseases such as glaucoma [51].

3.3. Lens. The lens is most affected by oxidative damage, because it is an avascular structure and has a constant and spare production of lenticular proteins. It is highly exposed to UV radiation and shows a marked reduction of antioxidants levels in the lenticular nucleus. In addition, changes on the aqueous humor composition can affect the (inflammation of adjacent structures and metabolic disorders such as diabetes) $[5,51]$.

Lenticular metabolism is related to energy production for protein synthesis and maintenance of osmotic balance. The pentose phosphate pathway, via glucose-6-phosphate dehydrogenase (G-6-PD) activity, provides reducing equivalents (NADPH) for keeping the lens in a reduced state [40].

The mechanism proposed to explain the lenticular opacity is the oxidation of the crystalline $(\alpha, \beta$, and $\gamma$ crystalline), mainly lens proteins $[51,52]$. The photooxidation of thiol groups on lens crystallins produce disulfide adducts and molecules that lead to protein aggregation and hence the cataract development [5]. Besides protein aggregation, there are also alterations in the $\mathrm{Na}^{+} / \mathrm{K}^{+}$ATPase [51]. It has been determined that damage at the protein level by oxidative processes is increases with age in human lens and is significantly greater in those with cataracts than normally transparent crystalline [16]. An increase of cystine levels (disulfide groups) and a decrease in cysteine concentration (sulfhydryl groups) during the cataract genesis have been demonstrated. Also an increase in disulfide-sulfhydryl ratio from soluble and insoluble proteins of human cataractous lenses is higher when the lenticular opacification increases [53].

Ascorbic acid and GSH are major defence mechanisms against photo-oxidation in the lens and aqueous humor [15]. The concentration of GSH in the lenticular epithelium is as high as that in the liver and its concentration decreases by exposure to UV radiation [54] and cataracts cases [40].
No differences were found between erythrocyte antioxidant enzymes from animals with and without cataracts, but MDA plasma levels are increased and ascorbic acid concentrations decreased from animals with cataracts [49]. Others antioxidants present in lens, like lutein-zeaxanthin, retinoid, and tocopherol contents, do not show differences in concentration between normal and cataractous lenses [37], also, one study shows that concentration of $\alpha$-tocopherol was significantly higher in cataract lenses than clear lenses [55].

3.4. Retina. The retina is the neurosensorial tissue of the eye, and it is extremely rich in polyunsaturated lipids. This characteristic makes it particularly sensitive to ROS [56]. The main generation of ROS in the retina is due to the presence of cells with high oxygen consumption rate [57], exposure to UV radiation, and the presence of diseases that directly affect the vascular irrigation such as glaucoma [27].

In the retina, the light is focused directly on cells group located in a richly oxygenated place. The presence of a variety of pigments (melanin, lipofuscin, and lutein) provides an optimum condition for photosensitizing reactions, generating ROS. The outer segment photoreceptor membrane is rich in polyunsaturated lipids and is where most damage occurs [51].

The final common pathway of a group of diseases associated to decreased sensitivity and function of retinal ganglion cells, cells death, enlargement of the optic nerve head, visual field reduction, and blindness is glaucoma. Oxidative stress may contribute to the etiology and progression of glaucoma [58], the ischemia, and reperfusion process affects the retina increasing the nitric oxide production and other FRs in vitreous and aqueous humor [59]. The LPO is triggered, and it is considered the cause of injury and death of retinal ganglion cells and subsequent optic nerve damage [60]. Antioxidant protection exists in the retina, and this is mainly due to $\mathrm{C}$ and $\mathrm{E}$ vitamin, carotenoids, GPx, SOD and CAT enzymes, and GSH compound [29, 51, 61].

\section{Evaluation of Oxidative Stress}

The measurement of biomarkers of oxidative stress varies depending on the structure to be evaluated in the globe. Oxidant and antioxidant agents vary in the different ocular tissues and fluids. It is possible evaluate the protection and/or existing damage [32].

4.1. Protection Assessment. The antioxidant protection can be estimated by measurements of antioxidant compound concentrations (proteins, peptides, or vitamins), antioxidant enzyme activities, or the antioxidant capacity as a whole in each tissue or fluid of globe $[32,68]$.

The presence of SOD, GPx, and CAT in the globe can be evaluated in vitro using biochemical and immunohistochemical methods $[18,29,30]$. Also, it is possible to determine the SOD activity in situ [18]. Ascorbic acid, carotenoids, and tocopherols can be determined by high-pressure liquid chromatography (HPLC) $[29,32,37,48]$. The activity of fat-soluble antioxidants can be estimated by quantifying the resistance to oxidation of low density lipoprotein [6]. 
TABLE 1: Incidence of eye disease compared with antioxidant intake and/or plasma levels of antioxidants molecules in humans.

\begin{tabular}{|c|c|c|c|}
\hline Authors & Objective & Antioxidants & Conclusion \\
\hline $\begin{array}{l}\text { Berendschot et al. } \\
(2002)[62]\end{array}$ & $\begin{array}{l}376 \text { subjects of } 18 \text { to } 75 \text { years. To investi- } \\
\text { gate whether serum levels of antioxidants } \\
\text { influence the lens optical density. }\end{array}$ & $\begin{array}{l}\text { Lutein, zeaxanthin, Vit. } \\
\text { C, and } \alpha \text {-tocopherol. }\end{array}$ & $\begin{array}{l}\text { High serum levels of lutein and zeax- } \\
\text { anthin may retard aging of the lens. }\end{array}$ \\
\hline $\begin{array}{l}\text { Delcourt et al. } \\
\text { (1999) [63] }\end{array}$ & $\begin{array}{l}2584 \text { subjects, }>60 \text { years. To determine } \\
\text { plasma levels of antioxidant enzymes } \\
\text { related with cataract and age-related mac- } \\
\text { ular degeneration. }\end{array}$ & Enzymes: GPx and SOD. & $\begin{array}{l}\text { High levels of plasma GPx were } \\
\text { associated with age-related macular } \\
\text { degeneration and cataract prevalence. } \\
\text { High levels of plasma SOD were asso- } \\
\text { ciated with high cataract prevalence. }\end{array}$ \\
\hline $\begin{array}{l}\text { Delcourt et al. } \\
\text { (2003) [64] }\end{array}$ & $\begin{array}{l}1947 \text { subjects, }>60 \text { years. To determine the } \\
\text { association between antioxidant enzymes } \\
\text { activity and incidence of cataract. }\end{array}$ & Enzymes: SOD and GPx. & $\begin{array}{l}\text { High levels of plasma GPx and SOD } \\
\text { were associated with high cataract } \\
\text { incidence. }\end{array}$ \\
\hline $\begin{array}{l}\text { Gale et al. } \\
(2001)[65]\end{array}$ & $\begin{array}{l}372 \text { subjects of } 66 \text { to } 75 \text { years. To deter- } \\
\text { mine plasma levels of some vitamins } \\
\text { and carotenoids related with cataract risk } \\
\text { incidence. }\end{array}$ & $\begin{array}{l}\text { Vit. C, Vit. E, } \alpha \text { and } \\
\beta \text {-carotene, lycopene, } \\
\text { lutein, zeaxanthin, and } \\
\beta \text {-cryptoxanthin. }\end{array}$ & $\begin{array}{l}\text { High levels of } \alpha \text {-carotene, } \beta \text {-carotene, } \\
\text { lycopene and lutein were associated } \\
\text { with low risk of cataract. }\end{array}$ \\
\hline $\begin{array}{l}\text { Jacques et al. } \\
(2001)[66]\end{array}$ & $\begin{array}{l}478 \text { women of } 53 \text { to } 73 \text { years. To assess } \\
\text { the relation between usual nutrient intake, } \\
\text { plasma vitamins concentration and sub- } \\
\text { sequently diagnosed age-related nuclear } \\
\text { lens opacities. }\end{array}$ & $\begin{array}{l}\text { Vit. C, Vit. E, riboflavin, } \\
\beta \text {-carotene, lutein, and } \\
\text { zeaxanthin. }\end{array}$ & $\begin{array}{l}\text { High Vit. C intake is associated with } \\
\text { low risk of cataract incidence. High } \\
\text { Vit. C and Vit. E plasma concentra- } \\
\text { tions are associated with low lenticu- } \\
\text { lar opacity. }\end{array}$ \\
\hline $\begin{array}{l}\text { Lyle et al. } \\
\text { (1999) [67] }\end{array}$ & $\begin{array}{l}400 \text { subjects of } 50 \text { to } 86 \text { years, } 7 \text { years } \\
\text { followup. To assess the relation of serum } \\
\text { carotenoids and tocopherols levels to the } \\
\text { incidence of cataract. }\end{array}$ & $\begin{array}{l}\text { Carotenoids, } \\
\alpha \text {-tocopherol, and } \\
\gamma \text {-tocopherol. }\end{array}$ & $\begin{array}{l}\text { High serum levels of tocopherols are } \\
\text { associated with low risk of cataract. }\end{array}$ \\
\hline
\end{tabular}

Vit. C: vitamin C; Vit. E: vitamin E; GPx: glutathione peroxidase; SOD: superoxide dismutase; CAT: catalase.

TABLE 2: Animal research comparing antioxidants and/or plasma levels of antioxidants molecules with degenerative changes in dogs.

\begin{tabular}{|c|c|c|c|}
\hline Authors & Objective & Antioxidants & Conclusion \\
\hline Barros et al. (1999) [49] & $\begin{array}{l}\text { To determine the erythrocytic } \\
\text { enzymatic antioxidants, plasma } \\
\text { Vit. C and MDA in normal } \\
\text { and cataractous English Cocker } \\
\text { Spaniel dogs. }\end{array}$ & $\begin{array}{l}\text { Enzymes: SOD, CAT, } \\
\text { GPx, and G6PD. } \\
\text { Vit. C. }\end{array}$ & $\begin{array}{l}\text { Decrease levels of plasma Vit. C are } \\
\text { related with cataract. }\end{array}$ \\
\hline Barros et al. (2003) [32] & $\begin{array}{l}\text { To determined the antioxidant } \\
\text { status of the aqueous humor after } \\
\text { extracapsular lens extraction. }\end{array}$ & $\begin{array}{l}\text { Total antioxidant status } \\
\text { and Vit C. }\end{array}$ & $\begin{array}{l}\text { Lens surgical procedures reduced } \\
\text { total antioxidant status and Vit. C } \\
\text { levels. }\end{array}$ \\
\hline Barros et al. (2004) [69] & $\begin{array}{l}\text { To determined levels of enzy- } \\
\text { matic and nonenzymatic antiox- } \\
\text { idants in blood and aqueous } \\
\text { humor of cataractous and non- } \\
\text { cataractous poodles. }\end{array}$ & $\begin{array}{l}\text { Enzymes: SOD, CAT, } \\
\text { GPx, and G6PD. } \\
\text { Vit. C. }\end{array}$ & $\begin{array}{l}\text { Activity of SOD, G6PD, and CAT was } \\
\text { significantly higher in noncataractous } \\
\text { poodles than in cataractous poodles. } \\
\text { There was no difference in mean } \\
\text { plasma Vit. C concentration between } \\
\text { cataractous and noncataractous dogs. }\end{array}$ \\
\hline De Biaggi et al. (2006) [48] & $\begin{array}{l}\text { To determined the antioxidant } \\
\text { status of the aqueous humor after } \\
\text { phacoemulsification. }\end{array}$ & $\begin{array}{l}\text { Total antioxidant status } \\
\text { and Vit. C. }\end{array}$ & $\begin{array}{l}\text { Lens surgical procedures reduced } \\
\text { total antioxidant status and Vit. C } \\
\text { levels. }\end{array}$ \\
\hline
\end{tabular}

Vit. C: vitamin C; GPx: glutathione peroxidase; SOD: superoxide dismutase; CAT: catalase; MDA: malondialdehyde; G6PD: glucose-6-phosphate dehydrogenase.

To evaluate the total antioxidant capacity is accepted to determine the capacity of the tissue or fluid to inhibit a specific free radical $[32,48,68]$ or determine the GSH/GSSG ratio and ascorbic acid/dehydroascorbate ratio [6].

4.2. Damage Assessment. To assess the damage, we can use the identification and quantification of proteins, lipids, and other substances from damaged cell. The biomarkers frequently used are carbonyl and sulfhydryl levels [16]. In the course of an oxidative process, carbonyl groups are formed into the amino acid chain mainly in the lysine, arginine, proline, and histidine residues. These carbonyl can be detected by spectrophotometric methods, highpressure liquid chromatography (HPLC), or enzyme-linked 
immunosorbent assay (ELISA) technique. To assess the integrity of lipids, the measurement of membrane lipid peroxidation is a key indicator [70]. The most common method for assessing LPO, due to its simplicity and low cost, is the measurement of MDA as thiobarbituric acid reactive substance (TBARS) $[6,70]$.

\section{Conclusions}

As mentioned, the eye is exposed to oxidizing conditions that lead to an alteration of ocular tissue, impaired vision, and, in turn, the animal's relationship with the surrounding environment. The importance of assessing oxidative stress in the globe lies in identifying the magnitude and extent of damage that occurs in this condition. It is necessary to establish treatment regimens to prevent and repair damage by ROS. This last point is being addressed by some research groups inducing or determining the incidence of ocular diseases and comparing the intake of antioxidants and/or blood levels of these (Table 1). It is established that it is important to have an optimal level of antioxidants to maintain ocular tissues safe, but it is not clear if consumption of those antioxidant could help to achieve this gold. Veterinary literature in this topic seems to be limited (Table 2).

Models to study oxidative stress have yielded promising results in relation with the use of antioxidants in diet. However, the results cannot be completely confirmed because of the inability to measure accurately the intake of antioxidants in humans, and also it is unlikely to extrapolate results from studies made in laboratory animals. There are other drawbacks to recommend antioxidant intake due to the fact that it is possible that an excessive consumption can lead to other diseases such as formation of bladder stones by eating high concentrations of vitamin C. Negligent administration of supplements without having more knowledge of dosages and good employment conditions may actually speed up rather than suppress oxidative damage.

It would be desirable to know the normal antioxidant status of the eye in each animal species and have better or less invasive ways to evaluate it, such as measure blood antioxidant profile and determine how it relates to the antioxidant profile or damage of a specific ocular tissue. It is also an important goal find different ways to strengthening antioxidant defences and stop oxidative damage. There is an open door to start new research in this area with many questions to resolve.

\section{References}

[1] R. Saxena, S. Srivastava, D. Trivedi, E. Anand, S. Joshi, and S. K. Gupta, "Impact of environmental pollution on the eye," Acta Ophthalmologica Scandinavica, vol. 81, no. 5, pp. 491494, 2003.

[2] K. M. Newkirk, H. L. Chandler, A. E. Parent et al., "Ultraviolet radiation-induced corneal degeneration in 129 mice," Toxicologic Pathology, vol. 35, no. 6, pp. 817-824, 2007.

[3] J. K. Willcox, S. L. Ash, and G. L. Catignani, "Antioxidants and prevention of chronic disease," Critical Reviews in Food Science and Nutrition, vol. 44, no. 4, pp. 275-295, 2004.
[4] P. P. Lee, Z. W. Feldman, J. Ostermann, D. S. Brown, and F. A. Sloan, "Longitudinal prevalence of major eye diseases," Archives of Ophthalmology, vol. 121, no. 9, pp. 1303-1310, 2003.

[5] D. L. Williams, "Oxidation, antioxidants and cataract formation: a literature review," Veterinary Ophthalmology, vol. 9, no. 5, pp. 292-298, 2006.

[6] R. Chihuailaf, P. Contreras, and F. Wittwer, "Patogénesis del estrés oxidativo: consecuencias y evaluación en salud animal," Veterinaria México, vol. 33, pp. 265-283, 2002.

[7] B. Halliwell, J. M. C. Gutteridge, and C. E. Cross, "Free radicals, antioxidants, and human disease: where are we now?" Journal of Laboratory and Clinical Medicine, vol. 119, no. 6, pp. 598-620, 1992.

[8] B. Halliwell and S. Chirico, "Lipid peroxidation: its mechanism, measurement, and significance," American Journal of Clinical Nutrition, vol. 57, supplement 5, pp. 715S-724S, 1993.

[9] D. Benítez, "Vitaminas y oxidorreductasas antioxidantes: defensa ante el estrés oxidativo," Revista Cubana de Investigaciones Biomedicas, vol. 25, no. 2, pp. 1-8, 2006.

[10] N. Punchard and F. Kelly, Free Radicals-A Practical Approach, Oxford University Press, New York, NY, USA, 1997.

[11] C. M. Deaton and D. J. Marlin, "Exercise-associated oxidative stress," Clinical Techniques in Equine Practice, vol. 2, no. 3, pp. 278-291, 2003.

[12] S. Galecio, Lipoperoxidación y daño muscular producto del ejercicio en equinos criollo Chileno y su relación con la actividad sanguínea de glutatión peroxidasa, Memoria Magíster en Ciencias. thesis, Facultad de Ciencias Veterinarias, Universidad Austral de Chile, Valdivia, Chile, 2007.

[13] M. Martínez-Cayuela, "Toxicidad de xenobióticos mediada por radicales libres de oxígeno," Ars Pharmaceutica, vol. 39, no. 1, pp. 5-18, 1998.

[14] B. Yu, "Cellular defenses against damage from reactive oxygen species," Physiological Reviews, vol. 74, no. 1, pp. 139-162, 1994.

[15] A. Taylor, P. F. Jacques, and E. M. Epstein, "Relations among aging, antioxidant status, and cataract," American Journal of Clinical Nutrition, vol. 62, supplement 6, pp. 1439s-1447s, 1995.

[16] F. Boscia, I. Grattagliano, G. Vendemiale, T. Micelli-Ferrari, and E. Altomare, "Protein oxidation and lens opacity in humans," Investigative Ophthalmology and Visual Science, vol. 41, no. 9, pp. 2461-2465, 2000.

[17] S. D. Varma, "Scientific basis for medical therapy of cataracts by antioxidants," American Journal of Clinical Nutrition, vol. 53, supplement 1, pp. 335s-345s, 1991.

[18] J. Čejková, S. Štípek, J. Crkovská et al., "UV rays, the prooxidant/antioxidant imbalance in the cornea and oxidative eye damage," Physiological Research, vol. 53, no. 1, pp. 1-10, 2004.

[19] L. L. Ji, "Oxidative stress during exercise: implication of antioxidant nutrients," Free Radical Biology and Medicine, vol. 18, no. 6, pp. 1079-1086, 1995.

[20] J. Čejková, S. Štípek, J. Crkovská, and T. Ardan, "Changes of superoxide dismutase, catalase and glutathione peroxidase in the corneal epithelium after UVB rays. Histochemical and biochemical study," Histology and Histopathology, vol. 15, no. 4, pp. 1043-1050, 2000.

[21] A. Bilgihan, K. Bilgihan, Ö. Yis, C. Sezer, G. Akyol, and B. Hasanreisoglu, "Effects of topical vitamin E on corneal superoxide dismutase, glutathione peroxidase activities and polymorphonuclear leucocyte infiltration after photorefractive keratectomy," Acta Ophthalmologica Scandinavica, vol. 81, no. 2, pp. 177-180, 2003. 
[22] A. Behndig, K. Karlsson, B. O. Johansson, T. Brännström, and S. L. Marklund, "Superoxide dismutase isoenzymes in the normal and diseased human cornea," Investigative Ophthalmology and Visual Science, vol. 42, no. 10, pp. 2293-2296, 2001.

[23] B. Ozmen, D. Ozmen, E. Erkin, I. Güner, S. Habif, and O. Bayindir, "Lens superoxide dismutase and catalase activities in diabetic cataract," Clinical Biochemistry, vol. 35, no. 1, pp. 6972, 2002.

[24] A. Satici, M. Guzey, B. Gurler, H. Vural, and T. Gurkan, "Malondialdehyde and antioxidant enzyme levels in the aqueous humor of rabbits in endotoxin-induced uveitis," European Journal of Ophthalmology, vol. 13, no. 9-10, pp. 779$783,2003$.

[25] A. C. Phylactos and W. G. Unger, "Biochemical changes induced by intravitreally-injected doxorubicin in the irisciliary body and lens of the rabbit eye," Documenta Ophthalmologica, vol. 95, no. 2, pp. 145-155, 1998.

[26] R. N. Frank, R. H. Amin, and J. E. Puklin, "Antioxidant enzymes in the macular retinal pigment epithelium of eyes with neovascular age-related macular degeneration," American Journal of Ophthalmology, vol. 127, no. 6, pp. 694-709, 1999.

[27] C. D. Agardh, C. Gustavsson, P. Hagert, M. Nilsson, and E. Agardh, "Expression of antioxidant enzymes in rat retinal ischemia followed by reperfusion," Metabolism: Clinical and Experimental, vol. 55, no. 7, pp. 892-898, 2006.

[28] J. Čejková, M. Vejražka, J. Pláteník, and S. Štípek, “Agerelated changes in superoxide dismutase, glutathione peroxidase, catalase and xanthine oxidoreductase/xanthine oxidase activities in the rabbit cornea," Experimental Gerontology, vol. 39, no. 10, pp. 1537-1543, 2004.

[29] J. S. Penn, L. A. Thum, and M. I. Naash, "Oxygen-induced retinopathy in the rat: vitamins $\mathrm{C}$ and $\mathrm{E}$ as potential therapies," Investigative Ophthalmology and Visual Science, vol. 33, no. 6, pp. 1836-1845, 1992.

[30] S. Zhang, F. Y. Chai, H. Yan, Y. Guo, and J. J. Harding, "Effects of N-acetylcysteine and glutathione ethyl ester drops on streptozotocin-induced diabetic cataract in rats," Molecular Vision, vol. 14, pp. 862-870, 2008.

[31] R. F. Brubaker, W. M. Bourne, L. A. Bachman, and J. W. McLaren, "Ascorbic acid content of human corneal epithelium," Investigative Ophthalmology and Visual Science, vol. 41, no. 7, pp. 1681-1683, 2000.

[32] P. S. M. Barros, C. F. Padovani, V. V. Silva, L. Queiroz, and S. B. M. Barros, "Antioxidant status of dog aqueous humor after extracapsular lens extraction," Brazilian Journal of Medical and Biological Research, vol. 36, no. 11, pp. 1491-1494, 2003.

[33] A. Ringvold, E. Anderssen, and I. Kjonniksen, "Distribution of ascorbate in the anterior bovine eye," Investigative Ophthalmology and Visual Science, vol. 41, no. 1, pp. 20-23, 2000.

[34] Y. Ohta, T. Niwa, and T. Yamasaki, "Short-term ascorbic acid deficiency does not impair antioxidant status in lens of guinea pigs," Journal of Nutritional Science and Vitaminology, vol. 50, no. 2, pp. 149-153, 2004.

[35] K. Koide, X. M. Zhang, K. Ohishi, Y. Usami, Y. Hotta, and T. Hiramitsu, "Ascorbic acid concentration in rabbit vitreous measured by microdialysis with HPLC-electrochemical detection before and after vitreous surgery," Experimental Eye Research, vol. 82, no. 5, pp. 868-873, 2006.

[36] S. K. Powers and S. L. Lennon, "Analysis of cellular responses to free radicals: focus on exercise and skeletal muscle," Proceedings of the Nutrition Society, vol. 58, no. 4, pp. 10251033, 1999.
[37] K. J. Yeum, A. Taylor, G. Tang, and R. M. Russell, "Measurement of carotenoids, retinoids, and tocopherols in human lenses," Investigative Ophthalmology and Visual Science, vol. 36, no. 13, pp. 2756-2761, 1995.

[38] P. S. Bernstein, F. Khachik, L. S. Carvalho, G. J. Muir, D. Y. Zhao, and N. B. Katz, "Identification and quantitation of carotenoids and their metabolites in the tissues of the human eye," Experimental Eye Research, vol. 72, no. 3, pp. 215-223, 2001.

[39] H. Sasaki, F. J. Giblin, B. S. Winkler, B. Chakrapani, V. Leverenz, and S. Chu-Chen, "A protective role for glutathionedependent reduction of dehydroascorbic acid in lens epithelium," Investigative Ophthalmology and Visual Science, vol. 36, no. 9, pp. 1804-1817, 1995.

[40] H. Sasaki, F. J. Giblin, B. S. Winkler, B. Chakrapani, V. Leverenz, and S. Chu-Chen, "A protective role for glutathionedependent reduction of dehydroascorbic acid in lens epithelium," Investigative Ophthalmology and Visual Science, vol. 36, no. 9, pp. 1804-1817, 1995.

[41] R. Kannan, D. Tang, J. B. Mackic, B. V. Zlokovic, and J. C. Fernandez-Checa, "A simple technique to determine glutathione (GSH) levels and synthesis in ocular tissues as GSH-bimane adduct: application to normal and galactosemic guinea-pigs," Experimental Eye Research, vol. 56, no. 1, pp. 4550, 1993.

[42] S. Zigman, "Ocular light damage," Photochemistry and Photobiology, vol. 57, no. 6, pp. 1060-1068, 1993.

[43] L. Kolozsvari, A. Nogradi, B. Hopp, and Z. Bor, "UV absorbance of the human cornea in the 240- to 400-nm range," Investigative Ophthalmology and Visual Science, vol. 43, pp. 2165-2168, 2002.

[44] E. Haaskjold, W. M. Olsen, R. Bjerknes, and K. Kravik, "Early cell kinetic effects of a single dose of narrow-banded ultraviolet B irradiation on the rat corneal epithelium," Photochemistry and Photobiology, vol. 57, no. 4, pp. 663-666, 1993.

[45] S. Löfgren and P. G. Söderberg, "Lens lactate dehydrogenase inactivation after UV-B irradiation: an in vivo measure of UVR-B penetration," Investigative Ophthalmology and Visual Science, vol. 42, no. 8, pp. 1833-1836, 2001.

[46] J. Čejková and Z. Lojda, "Histochemical study on xanthine oxidase activity in the normal rabbit cornea and lens and after repeated irradiation of the eye with UVB rays," Acta Histochemica, vol. 98, no. 1, pp. 47-52, 1996.

[47] R. Carubelli, R. E. Nordquist, and J. J. Rowsey, "Role of active oxygen species in corneal ulceration. Effect of hydrogen peroxide generated in situ," Cornea, vol. 9, no. 2, pp. 161-169, 1990.

[48] C. P. De Biaggi, P. S. M. Barros, V. V. Silva, D. E. Brooks, and S. B. M. Barros, "Ascorbic acid levels of aqueous humor of dogs after experimental phacoemulsification," Veterinary Ophthalmology, vol. 9, no. 5, pp. 299-302, 2006.

[49] P. S. M. Barros, A. C. Angelotti, F. Nobre, A. Morales, D. T. Fantoni, and S. B. M. Barros, "Antioxidant profile of cataractous English Cocker Spaniels," Veterinary Ophthalmology, vol. 2, no. 2, pp. 83-86, 1999.

[50] M. L. Cheng, T. Z. Liu, F. J. Lu, and D. T. Y. Chiu, "Simultaneous detection of vitamin $\mathrm{C}$ and uric acid by capillary electrophoresis in plasma of diabetes and in aqueous humor in acute anterior uveitis," Clinical Biochemistry, vol. 32, no. 6, pp. 473-476, 1999.

[51] U. Andley, "Photodamage to the eye: yearly review," Photochemistry and Photobiology, vol. 46, pp. 1057-1066, 1987. 
[52] R. J. W. Truscott, "Age-related nuclear cataract-oxidation is the key," Experimental Eye Research, vol. 80, no. 5, pp. 709725, 2005.

[53] O. P. Kulshrestha, S. N. Kulshrestha, K. P. Khuteta, and Y. Shukla, "Study of cysteine, cystine and methionine in normal and cataractous human lenses," Indian Journal of Ophthalmology, vol. 31, no. 3, pp. 267-269, 1983.

[54] V. C. Mody Jr., M. Kakar, A. Elfving, P. G. Söderberg, and S. Löfgren, "Ultraviolet radiation-B-induced cataract in albino rats: maximum tolerable dose and ascorbate consumption," Acta Ophthalmologica Scandinavica, vol. 84, no. 3, pp. 390395, 2006.

[55] K. Krepler and R. Schmid, "Alpha-tocopherol in plasma, red blood cells and lenses with and without cataract," American Journal of Ophthalmology, vol. 139, no. 2, pp. 266-270, 2005.

[56] M. Miranda, M. Muriach, J. Roma et al., "Oxidative stress in a model of experimental diabetic retinopathy: the utility of peroxinytrite scavengers," Archivos de la Sociedad Espanola de Oftalmologia, vol. 81, no. 1, pp. 27-32, 2006.

[57] L. Wang, M. Kondo, and A. Bill, "Glucose metabolism in cat outer retina: effects of light and hyperoxia," Investigative Ophthalmology and Visual Science, vol. 38, no. 1, pp. 48-55, 1997.

[58] J. H. Kang, L. R. Pasquale, W. Willett et al., "Antioxidant intake and primary open-angle glaucoma: a prospective study," American Journal of Epidemiology, vol. 158, no. 4, pp. 337-346, 2003.

[59] M. E. Källberg, D. E. Brooks, K. N. Gelatt, G. A. GarciaSanchez, N. J. Szabo, and G. N. Lambrou, "Endothelin-1, nitric oxide, and glutamate in the normal and glaucomatous dog eye," Veterinary Ophthalmology, vol. 10, no. 1, pp. 46-52, 2007.

[60] L. A. Levin, J. A. Clark, and L. K. Johns, "Effect of lipid peroxidation inhibition on retinal ganglion cell death," Investigative Ophthalmology and Visual Science, vol. 37, no. 13, pp. 27442749, 1996.

[61] Y. Nakajima, Y. Inokuchi, M. Shimazawa, K. Otsubo, T. Ishibashi, and H. Hara, "Astaxanthin, a dietary carotenoid, protects retinal cells against oxidative stress in-vitro and in mice in-vivo," Journal of Pharmacy and Pharmacology, vol. 60, no. 10, pp. 1365-1374, 2008.

[62] T. T. J. M. Berendschot, W. M. R. Broekmans, I. A. A. Klöpping-Ketelaars, A. F. M. Kardinaal, G. Poppel, and D. Norren, "Lens aging in relation to nutritional determinants and possible risk factors for age-related cataract," Archives of Ophthalmology, vol. 120, no. 12, pp. 1732-1737, 2002.

[63] C. Delcourt, J. P. Cristol, C. L. Léger, B. Descomps, and L. Papoz, "Associations of antioxidant enzymes with cataract and age-related macular degeneration: the POLA study," Ophthalmology, vol. 106, no. 2, pp. 215-222, 1999.

[64] C. Delcourt, I. Carrière, M. Delage, B. Descomps, J. P. Cristol, and L. Papoz, "Associations of cataract with antioxidant enzymes and other risk factors: the French age-related eye diseases (POLA) prospective study," Ophthalmology, vol. 110, no. 12, pp. 2318-2326, 2003.

[65] C. R. Gale, N. F. Hall, D. I. W. Phillips, and C. N. Martyn, "Plasma antioxidant vitamins and carotenoids and age-related cataract," Ophthalmology, vol. 108, no. 11, pp. 1992-1998, 2001.

[66] P. F. Jacques, L. T. Chylack Jr., S. E. Hankinson et al., "Long-term nutrient intake and early age-related nuclear lens opacities," Archives of Ophthalmology, vol. 119, no. 7, pp. 1009-1019, 2001.
[67] B. J. Lyle, J. A. Mares-Perlman, B. E. K. Klein et al., "Serum carotenoids and tocopherols and incidence of age-related nuclear cataract," American Journal of Clinical Nutrition, vol. 69, no. 2, pp. 272-277, 1999.

[68] A. Nemec, M. Drobnič-Košorok, M. Skitek, Z. Pavlica, S. Galac, and J. Butinar, "Total antioxidant capacity (TAC) values and their correlation with individual antioxidants in serum of healthy beagles," Acta Veterinaria Brno, vol. 69, no. 4, pp. 297303, 2000.

[69] P. S. M. Barros, A. M. V. Safatle, L. Queiroz, V. V. Silva, and S. B. M. Barros, "Blood and aqueous humour antioxidants in cataractous poodles," Canadian Journal of Ophthalmology, vol. 39, no. 1, pp. 19-24, 2004.

[70] H. Esterbauer and K. H. Cheeseman, "Determination of aldehydic lipid peroxidation products: malonaldehyde and 4hydroxynonenal," Methods in Enzymology, vol. 186, pp. 407$421,1990$. 

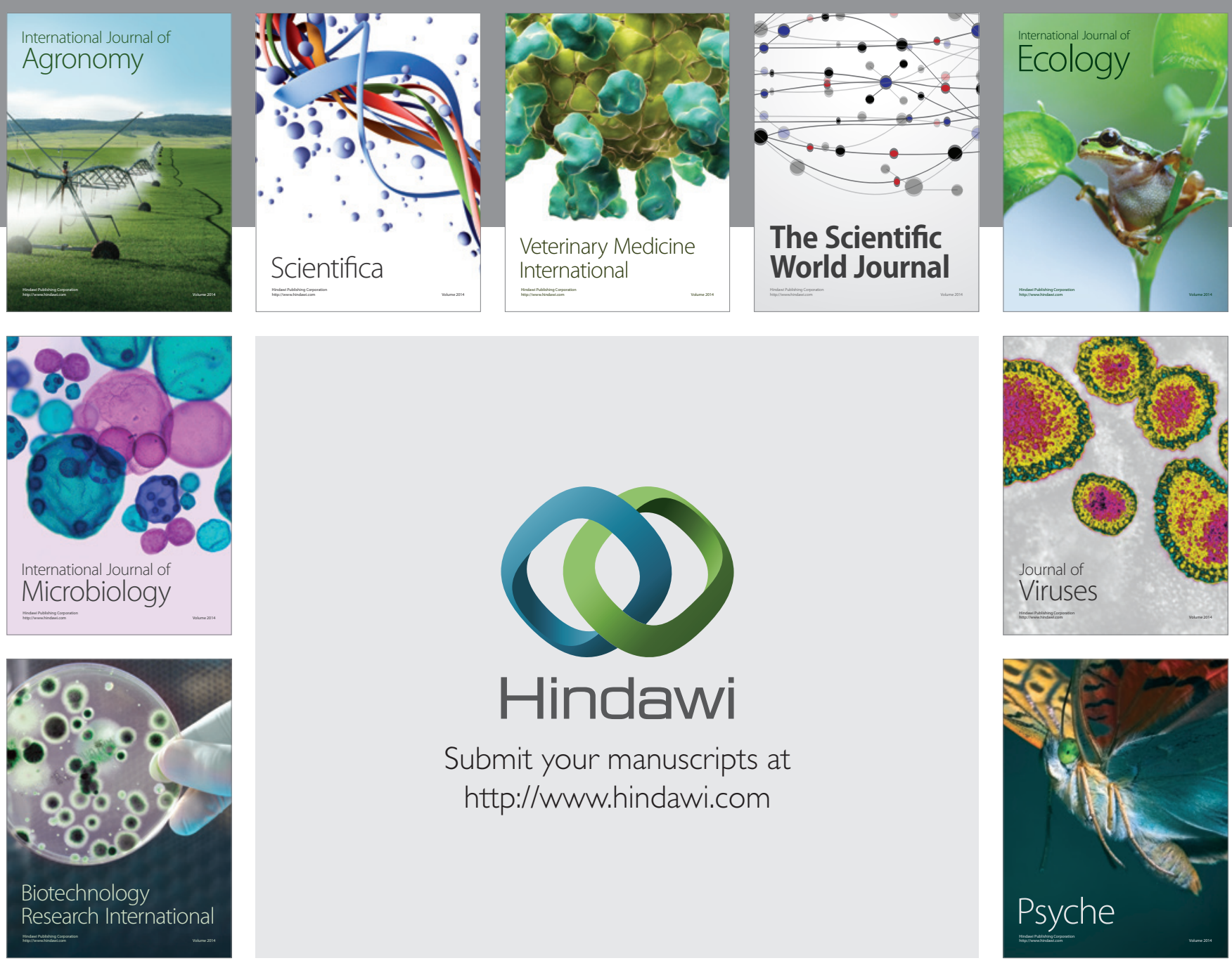

Submit your manuscripts at

http://www.hindawi.com
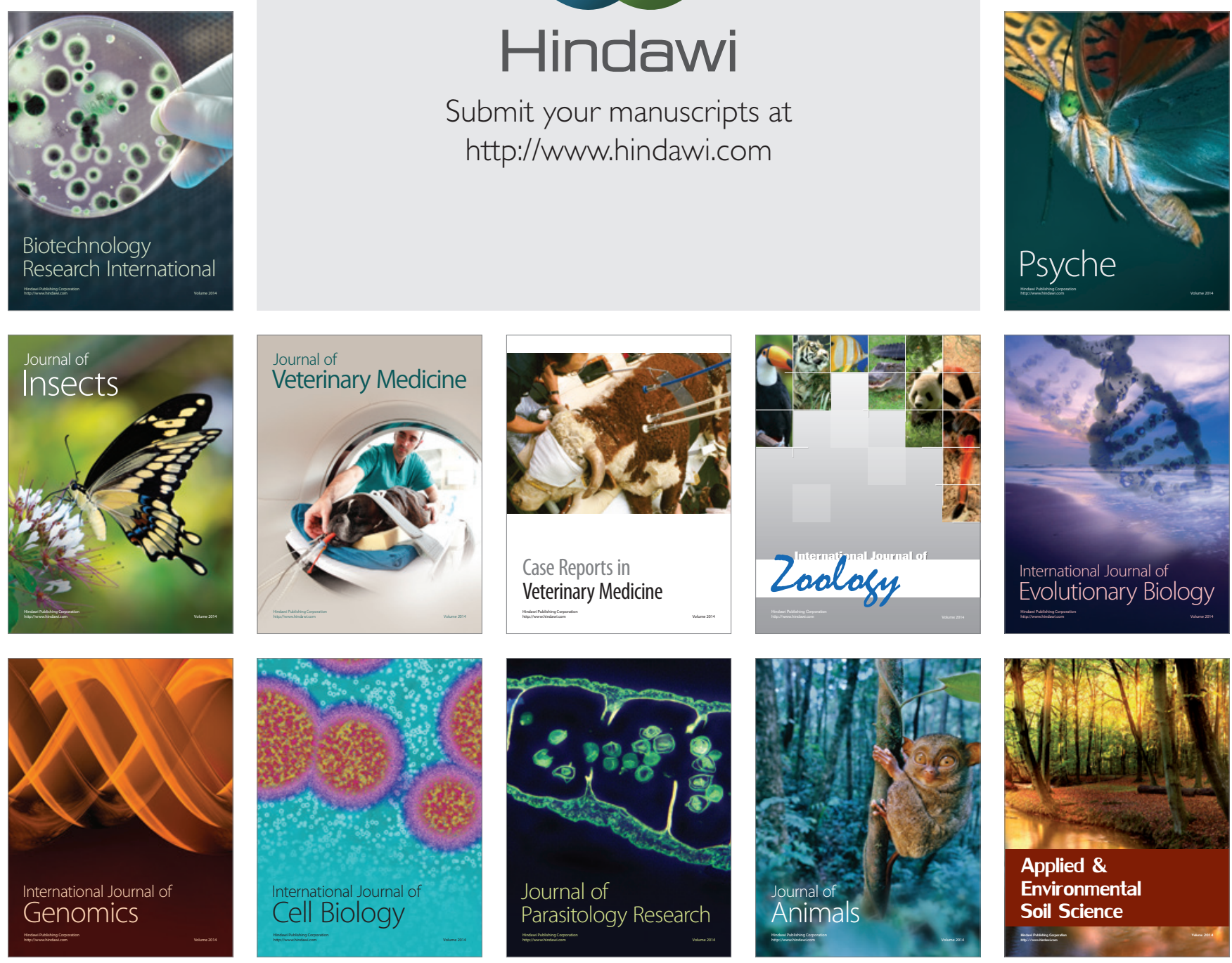